\title{
MODEL BANTUAN KEWIRAUSAHAAN \\ BERBASIS PENGEMBANGAN SDM SEBAGAI UPAYA MEWUJUDKAN KEMANDIRIAN EKONOMI MUSTAHIK
}

\author{
Maratus Sholikha \\ Fakultas Ekonomi UIN Maulana Malik Ibrahim Malang \\ Email: soliha.succes@gmail.com
}

\begin{abstract}
Human resources has important role to establish organization goals, in addition to accelerate realization of achievment goals, so it is needed a human resources development program as strategic step to fulfill needs of required abilities. This program is unlimited implementation by profit oriented organization, but included phylanthropy organization. This research use descriptive qualitative. The object of research is Rumah Zakat branch Malang, but it is focused on "Mustahik". The Data analysis technique use Analysis of data presentation method, data reduction, data display, conclusion and verification.

The result show that the implementation of development program is one of many ways to form the independence of Mustahik in the global era which require competitive supremacy like teoritic abilities, conceptual, moral and technical skills. The organization provide competent presentator on his expertise and more specifically in enterpreunership and this is necessary to deliver motivation for founder member. After all the implementation of enterpreunership assistance based on human resources development being good assumed and optimum is measured by knowledge, hard skill, soft skill, sharia competence and mainly watched on independence (financial, spiritual and social) mustahik since following this program although the output who is generated still slightter than expected.
\end{abstract}

Keyword Enterpreunership, Human Resources Development, Independence Mustahik

\section{PENDAHULUAN}

Indonesia merupakan salah satu Negara dengan potensi demografi yang besar dan mayoritas penduduknya memeluk agama islam. Besarnya penduduk muslim di Indonesia memberikan sinyal positif terhadap berkembangnya Lembaga Amil Zakat. Pada tahun 2016 potensi zakat di Indonesia mencapai Rp. 217 triliun yang nilainya hamper 10\% dari APBN. Adanya potensi yang bear ini zakat diharapkan mampu untuk membantu pemerintah mengentaskan kemiskinan dan membangkitkan kemandirian ekonomi serta mampu berperan lebih banyak dalam mendukung SDGs yng bertujuan mengentaskan kemiskinan, memerangi kesenjangan dan ketidakadilan, serta perubahan iklim pada tahun 2030. 
Zakat merupakan ajaran yang melandasi bertumbuh kembangnya sebuah Kekuatan sosial ekonomi umat Islam. Seperti empat rukun Islam yang lain, ajaran Zakat menyimpan beberapa dimensi yang kompleks meliputi nilai privat-publik, Vertikal-horizontal, serta ukhrawi duniawi.

Nilai tersebut merupakan landasan pengembangan kehidupan kemasyarakatan yang komprehensif. Apabila semua dimensi yang terkandung dalam ajaran zakat ini dapat diaktualisasikan, maka zakat akan menjadi sumber kekuatan yang sangat besar bagi pembangunan Umat menuju kebangkitan kembali peradaban Islam (Idris, 1997; dalam Sudirman, 2007:1). Ajaran mulia dalam islam ini sebagai salah satu solusi dalam mengentaskan angka kemiskinan Indonesia yang jumlahnya mencapai 28,01 juta jiwa (BPS: Maret 2016).

Berdasarkan fakta bahwa kondisi perekonomian umat Islam dinilai masih tertinggal jauh dari perkembangan teknologi yang semakin maju, maka hal ini menjadi faktor penting dalam mendorong pemberdayaan masyarakat, sehingga diperlukan konsep pemberdayaan.

RZ berkomitmen tinggi dalam melakukan pemberdayaan masyarakat lebih khusus pada bidang ekonomi, hal ini tentu sangat berbeda dengan lembaga atau peruahaan lainnya yang hanya memberikan dana tanpa pembinaan intensif yang berkelanjutan. Salah satu upaya untuk mewujudkan kemandirian mustahik untuk bia bersaing menghadapi persaingan global adalah dengan jalan program pengembangan. Program pengembangan berupa pelatihan rutin satu bulan sekali. Hal ini dapat diartikan bahwa dalam satu tahun pelatihan telah diadakan minimal 12 kali.

Untuk itu diperlukan peran serta seluruh elemen masyarakat dalam menunjang kemandirian ekonomi masyarakat kurang mampu. Salah satu lembaga filantropi yang konsisten dalam pengelolaan dana sosial seperti zakat, infak, shodaqah dan dana kebajikan lainnya berbasis pemberdayaan masyarakat adalah Rumah Zakat (RZ). Sebagai upaya mewujudkan kemandirian mustahik di era persaingan global yang menuntut adanya keunggulan competitive berupa keahlian teoritis, konseptual, moral, dan keterampilan teknis maka, RZ Malang memiliki progam pengembangan.

Pada dasarnya manusia memerlukan pelatihan dan pengembangan agar terbentuk individu-individu yang baik yang sanggup memikul amanah dan beban yang diberikan. Demikian pula, perusahaan akan memenangkan persaingan ketika memiliki asset (human capital) berupa SDI yang amanah dan profesional, yaitu SDI yang berkualitas dan berdaya saing. Di sisi lain 
perlunya pelatihan dan pengembangan SDI juga berdasarkan prinsip Islam yang mengedepankan semangat sebagaimana pesan Rasulullah:

"hari ini harus lebih baik dari hari kemarin. Hari esok harus lebih baik daripada hari ini. Barangsiapa yang hari ini lebih buruk dari hari kemarin, berarti celaka. Barangsiapa yang hari ini sama saja dengan hari kemarin berarti merugi." (Zainal, 2014: 232-233)

Penelitian yang berkaitan dengan pengembangan SDM pada lembaga sosial diantaranya, penelitian ynag dilakukan oleh Rosadi (2015) "Pemberdayaan ekonomi mustahik berbasis zakat produktif oleh DPU- DT" (Dompet Peduli Ummat Daarut Tauhid) di Yogyakarta). Studi kasus Misykat Fastabiqul Khoirot Wonokromo, Pleret, Bantul, Yogyakarta. Menunjukkan bahwa Pertama, pemberdayaan ekonomi berbasis zakat produktif dalam progam MiSykat sangat berperan dalam upaya mengembangkan pengetahuan anggota dalam hal pengelolaan keuangan usaha-usaha anggota, saling membantu atau peka antar sesama serta mampu menanamkan nilainilai hidup yang baik di dalam kehidupan bermasyarakat seperti jujur, hidup hemat dan kerja keras. Kedua, berdampak pada pengembangan anggotanya seperti peningkatan penghasilan keluarga, peningkatan ketrampilan dan skill, serta membentuk karakter anggota yang baik. Semua itu dibingkai dalam satu wadah yaitu majelis MiSykat dengan cara mendorong, memotivasi, serta membangkitkan kesadaran akan potensi yag dimiliki dan berupaya untuk mengembangkan potensi itu menjadi sebuah tindakan yang nyata.

Berdasarkan penelitian yang dilakukan oleh peneliti terdahulu dapat menjadi rujukan atau referensi dalam membantu proses penelitian. Perbedaan terletak pada fokus penelitian, spesifikasi pada penelitian ini adalah mengkaji lebih dalam dari aspek-aspek SDM yang berkaitan dengan pengembangan melalui pelatihan yang diterapakan pada lembaga sosial seperti RZ. Fokus penelitian adalah pada penerapan pengembangan SDM yaitu mustahik melalui pelatihan. Peninjauan dilakukan pada salah satu progam pemberdayaan ekonomi pada devisi mandiri daya insani yang ada di lembaga tersebut. Maka penting kiranya penelitian ini dilakukan untuk mengetahui bagaimana perkembangan SDM yang menerima dana sosial tersebut.

Tujuan Penelitian adalah Mendeskripsikan bagaimana sistem pendistribusian dana bantuan kewirausahaan berbasis pengembangan SDM, 
penerapan pengembangan SDM dalam meningkatkan kompetensi mustahik, dan implikasi bantuan kewirausahaan berbasis pengembangan SDM dalam mewujudkan kemandirian ekonomi mustahik.

\section{KAJIAN PUSTAKA}

\section{Kewirausahaan}

Kewirausahaan merupakan suatu kemampuan dalam hal menciptakan kegiatan usaha. Kemampuan menciptakan memerlukan adanya kreativitas dan inovasi yang terus menerus untuk menemukan sesuatu yang berbeda dari yang sudah ada sebelumnya. Kreatifitas dan inovasi tersebut pada akhirnya mampu memberikan kontribusi bagi masyarakat banyak (Kasmir, 2007: 18). Secara normatif, ajaran Islam mendorong umatnya untuk bekerja keras secara bermoral. Dengan istilah lain, Islam memberikan dorongan dan landasan etik, moral dan spiritual bagi terwujudnya wirausaha muslim yang unggul (Yunus, 2008: 16-17).

Pada hakekatnya islam adalah agama yang mengajarkan nilai-nilai etik, moral dan spiritual yang berfungi sebagai pedoman hidup di segala bidang, tak terkecuali pada bidang ekonomi (Yunus, 2008 : 9). Daalam eniklopedia al Qur'an dikemukakan bahwa istilah yang relevan dengan etos kerja adalah "rizq". Istilah ini disebut sebanyak 112 kali dalam 41 surat. Disebutkan dalam QS. An-Nur:37-3 Allah menganjurkan optimisme manusia terhadap rezekinya dan ditegaskan juga dalam QS al-Najm : 39 (Yunus, 2008 : 13-14).

\section{Konsep dasar Zakat}

Zakat berarti suci, bertambah dan berkah. Dengan demikian zakat itu membersihkan (menyucikan) diri seseorang dan hrtanya, pahalanya bertambah, harta tumbuh (berkembangan) dan membawa berkah. Kewajiban zakat dalam islam memiliki makna yang sangat fundamental. Selain berkaitan dengan aspek-aspek ketuhanan, juga ekonomi dan sosial.

Diantara aspek ketuhanan adalah banyaknya ayat-ayat Al Qur'an yang menyebut masalah zakat, termasuk diantaranya 27 ayat yang menyandingkan kewajiban zakat dan kewajiban sholat secara bersamaan, diantaranya QS Al-Baqarah : 83; QS An Nisa :77 (Ali, $2006: 1$ ).

Dari aspek social, perintah zakat dapat dipahami sebagai satu kesatuan sistem yang tidak terpisahkan dalam pencapaian kesejahteraan soial ekonomi dan kemasyarakatan. Zakat diharapkan dapat meminimalisir 
kesenjangan pendapatan. Selain itu zakat diharapkan dapat meningkatkan dan menumbuhkan perekonomian, baik pada level individu mupun level soial masyarakat (Ali, 2006 : 1-2).

Zakat merupakan alat bantu social mandiri yang menjadi kewajiban moral bagi orang kaya untuk membantu mereka yang miskin dan terabaikan yang tidak mampu menoolong dirinya sendiri meskipun dengan skema jaminan social (Suprayitno, 2005 : 33).

Pemanfaatan dana zakat dapat dibedakan dalam empat bentuk, (Inoed, 2005:3): (1) Konsumtif tradisional adalah bahwa zakat dibagikan kepada mustahik dengan secara langsung untuk kebutuhan konsumsi seharihari. Pola ini merupakan progam jangka pendek dalam mengatasi permasalahan umat; (2) Konsumtif kreatif: merupakan zakat yang diwujudkan dalam bentuk dana konsumtif dan digunakan untuk membantu orang miskin dalam mengatasi permasalahan sosial dan ekonomi yang dihadapinya. Bantuan tersebut berupa beasiswa untuk para pelajar, bantuan sarana ibadah, bantuan alat pertanian; (3) Produktif tradisional adalah zakat yang diberikan dalam bentuk barang-barang produktif, dimana dengan menggunakan barang-barang tersebut, para mustahik dapat menciptakan suatu usaha; (4) Produktif kreatif : Pendistribusian zakat secara produktif kreatif adalah zakat yang diwujudkan dalam bentuk pemberian modal bergulir, baik untuk permodalan proyek sosial, seperti pembangunan sosial, sekolah, sarana kesehatan atau tempat ibadah maupun sebagai modal usaha untuk membantu atau bagi pengembangan usaha para pedagang atau pengusaha kecil.

\section{Pengembangan Sumber Daya Manusia}

Pada manajemen training syariah, disamping soft skill dan hard skill juga terdapat satu faktor penting yang perlu terus dijaga dan dikembangkan, yaitu syariah skill atau dapat juga dipahami sebagai syariah competence. Syariah competence lebih dimaknai sebagai suatu kompetensi yang dibutuhkan bagi para karyawan di industri syariah. Pada praktiknya, hal tersebut diwujudkan sebagai suatu rangkaian progam pelatihan dan workshop mengenai: Tauhid (akidah), syariah, dan muamalah sebagai suatu kesatuan (Fahmi, 2014:175).

\section{Kemandirian Ekonomi}

Kemandirian masyarakat merupakan suatu kondisi yang dialami oleh masyarakat yang ditandai dengan kemampuan memikirkan, memutuskan 
serta melakukan sesuatu yang dipandang tepat demi mencapai pemecahan masalah-masalah yang dihadapi dengan mempergunakan daya kemampuan yang dimiliki (Sumudiningrat, 2000: 82).

Kemandirian ekonomi dalam konteks berwirausaha menurut pandangan Islam bahwa kerja juga dianjurkan sebagaimana pendapat Syafi'i (2004:114) bahwa Islam senantiasa mengajarkan kepada umatnya agar berusaha untuk memenuhi kebutuhan hidupnya. Tidak dibenarkan seorang muslim berpangku tangan saja atau berdoa mengharapkan rezeki datang dari langit tanpa mengiringinya dengan usaha.

Kemandirian yang diajarkan Rasulullah SAW tiada lain bertujuan untuk membentuk pribadi-pribadi muslim menjadi pribadi kretif, mau berusaha dengan maksimal, pantang menyerah dan pantang menjadi beban orang lain, mampu mengembangkan diri dan gemar bersedekah dengan harta yang didapatkannya (Gymnastiar, 2005: 26).

\section{METODE PENELITIAN}

Penelitian ini adalah penelitian lapangan, yaitu sebagai penelitian yang datanya diperoleh dengan cara mengumpulkan dari pengamatan empiris lapangan atau kancah penelitian dengan pendekatan kualitatif (Arikunto, 2006: 131). Adapun jenis penelitian yang digunakan yaitu studi kasus. Peneliti melihat dan mendalami sebuah kasus yang terjadi pada lembaga sosial. Penelitian ini dilakukan di salah satu cabang lembaga sosial RZ Malang yang berlokasi di Jl. W.R. Supratman, Klojen, Malang, Kota Malang, Jawa Timur 65111.

Sumber pengambilan data yaitu data primer dan data sekunder. Adapun teknik yang digunakan adalah dengan metode observasi, dokumentasi, dan wawancara. Sedangkan langkah-langkah dalam proses analisis data yang dilakukan oleh peneliti adalah sebagai berikut : Reduksi data, display atau penyajian data, menarik kesimpulan (verifikasi).

\section{HASIL DAN PEMBAHASAN}

\section{Sistem Pendistribusian Progam Bantuan Kewirausahaan}

Pada pola model pendistribusian tidak diterapkan sistem bagi hasil selayaknya lembaga-lembaga atau perusahaan lainnya. Akan tetapi, RZ memberikan dana secara cuma-cuma atau dalam bentuk hibah kepada 
mustahik. Meskipun bantuan kewirausahaan diberikan secara gratis akan tetapi, lembaga tetap memperhatikan pengembangan SDM penerima dana. Hal tersebut dapat dilihat dari konsistensi lembaga dalam memberikan berbagai bentuk progam-progam pengembangan bagi mustahik sebagai penerima dana bantuan kewirausahaan. Pola pendistribusian dana bantuan kewirausahaan menggunakan pola produktif tradisional dan pola produktif kreatif. Menurut (Inoed, 2005:3) Produktif tradisional adalah zakat yang diberikan dalam bentuk barang-barang produktif, dimana dengan menggunakan barang-barang tersebut, para mustahik dapat menciptakan suatu usaha. RZ memberikan barang-barang produktif tradisional kepada mustahik untuk menunjang keberlangsungan usaha seperti mesin cuci, mesin jahit, gerobak dan etalase. Sedangkan pendistribusian zakat secara produktif kreatif adalah zakat yang diwujudkan dalam bentuk pemberian modal bergulir, baik untuk permodalan proyek sosial, seperti pembangunan sosial, sekolah, sarana kesehatan atau tempat ibadah maupun sebagai modal usaha untuk membantu atau bagi pengembangan usaha para pedagang atau pengusaha kecil.

\section{Penerapan Pengembangan SDM di RZ}

Untuk menunjang progam pengembangan RZ bekerjasama dengan berbagai pihak salah satunya adalah PT PLN selain pelatihan dalam bentuk outdoor juga diadakan pelatihan indoor biasanya dilakukan satu bulan sekali secara rutin. Selain pelatihan dalam bentuk soft skill, RZ juga memberikan pelatihan dalam bentuk hard skill. Lembaga menyediakan pemateri yang kompeten pada bidangnya lebih khusus pada bidang bisnis yaitu para praktisi yang telah sukses menjalankan bisnis dengan omset puluhan bahkan ratusan juta dengan tujuan mustahik semakin termotivasi untuk menjadi wirausahawan sukses. Selain mendatangkan pelatih dari luar juga mengoptimalkan potensi dari pihak internal untuk terlibat sebagai pemateri seperti fasilitator dan juga relawan. Analisis kebutuhan pengembangan dilakukan oleh RZ melalui kunjungan atau observasi langsung ke binaan. Fasilitator dengan dibantu oleh para relawan melakukan kunjungan rutin.

Model pemberdayaan di RZ yang diterapkan sama seperti halnya yang disampaikan oleh Jusmaliani (2011) yaitu dengan metode presentasi, intruksi yang dipandu, pembelajaran jarak jauh dan adventure learning. Secara keseluruhan penerapan pengembangan SDM untuk para mustahik sudah cukup baik dan optimal. Hal tersebut sebagaimana yang dirasakan oleh para mustahik yaitu dengan meningkatnya pengetahuan, hard skill, soft 
skill dan syariah competence. Efektivitas progam yang telah diterapkan di RZ sebagaimana yang disampaikan oleh Hartatik (2014) bahwa suatu progam penting untuk diadakan suatu evaluasi sebagai acuan terhadap progam selanjutnya. Progam pengembangan dinilai efektiF ketika memenuhi kelima tingkatan yaitu : reaction, learning, behaviors, organizational result, dan cost affectivity.

Melalui wawancara dapat disimpulkan bahwa ukuran keberhasilan progam pengembangan adalah sebagai berikut: finansial, spiritual, sosial. Perubahan dapat diukur dengan dua cara: penilian terhadap pemahaman dan perilaku mustahik. Kedua aspek tersebut memiliki hubungan yang erat antara keduanya, ketika mustahik memahami materi yang disampaikan maka akan berdampak dari perilakunya. Perubahan dapat dilihat dari tata cara mustahik berjualan, tata cara pelayanan kepada pelanggan, mencatat pengeluaran dan pemasukan sederhana, peningkatan ibadah ritual seperti sholat lima waktu dan tambahan ibadah sunah, menghargai waktu dengan disiplin. Selain itu progam pengembangan ini juga meningkatkan motivasi mustahik sehingga memberikan efek positif berupa semakin bertambahnya semangat untuk berusaha.

Konsep pengembangan SDM yang teraplikasi di RZ sesuai dengan pendapat Syafi'i (2004:114) bahwa Islam senantiasa mengajarkan kepada umatnya agar berusaha untuk memenuhi kebutuhan hidupnya. Tidak dibenarkan seorang muslim berpangku tangan saja atau berdoa mengharapkan rezeki datang dari langit tanpa mengiringinya dengan usaha.

\section{Implikasi Bantuan Kewirausahaan Berbasis Pengembangan SDM Sebagai Upaya Mewujudkan Kemandirian Mustahik}

Tolok ukur kemandirian mustahik teraplikasi dari berbagai dampak (finansial, spiritual dan sosial) yang telah dirasakan oleh mustahik sejak mendapatkan bantuan serta mengikuti progam pengembangan secara intensif. Progam pengembangan berperan aktif dalam mendukung kemandirian mustahik, mustahik secara mandiri telah dapat melakukan halhal sebagai berikut: kemampuan pembukuan keuangan sederhana, kemampuan pemasaran (online atau offline), kemampuan pelayanan pelanggan secara tepat, kemampuan menghasilkan laba diatas rata-rata, kemampuan memotivasi diri, kemampuan spiritual, kemampuan sosial.

Kondisi diatas sesuai dengan kriteria mandiri yang disampaikan oleh Sumudiningrat (2002) bahwa kemandirian masyarakat merupakan suatu 
kondisi yang dialami oleh masyarakat yang ditandai dengan kemampuan memikirkan, memutuskan serta melakukan sesuatu yang dipandang tepat demi mencapai pemecahan masalah-masalah yang dihadapi dengan mempergunakan daya yang dimiliki.

\section{KESIMPULAN}

Pola pendistribusian dana bantuan kewirausahaan menggunakan pola produktif tradisional dan pola produktif kreatif. Secara keseluruhan penerapan progam pengembangan dalam mengasah kemampuan mustahik termasuk kedalam pengelolaan SDI yang islami sesuai dengan yang disampaikan oleh Jusmaliani (2011) yaitu tujuan pengembangan bukan hanya untuk meningkatkan ketrampilan kerja akan tetapi juga sebagai media pembentukan karakter islami. Tolak ukur kemandirian mustahik teraplikasi dari berbagai dampak (finansial, spiritual, dan sosial) yang telah dirasakan oleh mustahik sejak mendapatkan bantuan serta mengikuti progam pengembangan secara intensif.

\section{SARAN}

Binaan yang telah dimandirikan perlu adanya kunjungan berkala untuk mengetahui apakah memang telah layak dikatakan sebagai muzakki. Hal ini juga penting untuk mengontrol usaha mustahik agar tetap berjalan sebagaimana mestinya. Pada progam pengembangan terkait pelatihan lintas fungsional diluar dari jenis usaha yang dijalankan oleh mustahik perlu adanya pengoptimalan. Sebagai lembaga cabang perlu adanya administrasi yang terinci dan transparan terkait laporan keuangan terhadap jumlah yang telah terdistribusikan dan nama-nama penerima pada semua bidang atau progam yang telah terealisasi. Hal ini penting untuk menunjang kepercayaan masyarakat terhadap operasi lembaga.

\section{DAFTAR PUSTAKA}

Ali, Nurdin. 2006. Zakat sebagai instrument dalam kebijakan fiscal. Jakarta : PT Raja Grafindo.

Arikunto, Suharsimi. 2006. Prosedur Penelitian Suatu Pendekatan Praktik. Jakarta : Rineka Cipta.

Gymnastiar, Abdullah. 2005. Malu jadi Benalu. Bandung : Khas MQ. 
Hartatik, Indah Puji. 2014. Buku Praktis Mengembangan SDM. Jogjakarta: Laksana

Jusmaliani. 2011. Pengelolaan Sumber Daya Insani. Jakarta : PT Bumi Aksara.

Kasmir. 2007. Kewirausahaan. Jakarta: PT Raja Grafindo Persada

Rosadi. 2015. Pemberdayaan Ekonomi Mustahik Berbasis Zakat Produktif. Skripsi. Fakultas Dakwah dan Komunikasi UIN Sunan Kalijaga, Yogyakarta.

Sudirman. 2007. Zakat dalam Pusaran Arus Modernitas. Malang: UIN Malang Press.

Sumudiningrat, G. 2000. Visi dan Misi Pembangunan Pertanian Berbasis Pemberdayaan. Yogyakarta : IDEA.

Suprayitno, A. 2005. Ekonomi Islam. Yogyakarta : Graha Ilmu.

Yunus, Muh. 2008. Islam dan Kewirausahaan Inovatif. Malang : UIN Malang Press 